\title{
James Turner, Philology. 1. The Forgotten Origins of the Modern Humanities, Oxford University Press, Princeton/Oxford, 2014, xxiv p. +550 p.
}

\author{
Adina Chirilă* \\ Faculty of Letters, History and Theology, West University, Bd. Vasile Pârvan 4, 300223 Timişoara, Romania
}

The fact that volume 65 (issue 1)/1990 of "Speculum" (Medieval Academy of America, Cambridge) was assigned to Philology could be interpreted in two ways: as a reverence to a discipline which, in medieval studies, was "the matrix out of which all else springs" (Nichols, 1990, p. 1), and also as a salutary intention concerning the recognition of its similar status in the larger field of modern humanities.

Comprising, along Stephen G. Nichols' introductory article, five views on what could have been the new philology ( $v$. the title of the issue), "suitable" to a modernity that would feed some spectacular movements in cognitive methodologies, the volume would first of all lead to a slightly contradictory conclusion, suggested by Howard Bloch's position on the matter: " $[\mathrm{t}]$ he new «New Philology» overlaps, but is not necessarily coterminous, with the original spirit of philology in that both presuppose: (1) the privileging the language over its referent in the production of meaning, which means that some attention is payed not only to what words mean but how they mean [...]; (2) the contextualizing of literature both with respect to historical process and with respect to other discourses of man, such as philosophy, anthropology, and the social sciences; and (3) the irreductibility of the letter within the process of literary understanding" (Bloch, 1990, p. 3839).

Philology, therefore, would renounce the rhetorical artifice of autolegitimation (Bloch, 1990, p. 38), remaining (with satisfaction!), in purpose and method, what it had always been. If the issue was to reduce the distance between a science of this sort and the contemporary humanities ("to minimize the isolation between..., Nichols, 1990, p. 1), this type of reiteration seemed to give the responsibility of solving it to the scholars of the latter; they were supposed to fully and willingly admit that " $[\mathrm{t}]$ o these and a host of other contemporary critical questions and approaches to literature, philology continues to serve as a handmaiden, furnishing the material basis on which they must stand”; and that "scholarship is not an absolute monarchy, but a republic, in which the handmaiden, while doing her job of preparing the necessities of life-intelligible texts and tools for their understanding - will also remain constantly watchful and critical of the nobility. To order the disciplines devoted to the understanding of literary texts hierarchically, in the shape of a pyramid with palæography at the base and semiotics at the apex, is tempting but dangerous, because such a model allows the semiotician as well as the literary critic in the middle ranges to remain above and aloof from the concerns of philology. Not just an ancillary discipline, philology is an attitude of respect for the datum, for the facts of the text and its contexts, which should be cultivated at all levels of our enterprise to understand and appraise.

Philology thus holds not only a material value, in that it provides the raw materials for understanding, but equally a disciplinary one, by continuously demanding that the intellectual systems built by interpreters or theoreticians be tested against and anchored in the realities of the subject matter." (Wenzel, 1990, p. 17-18).

Nevertheless, during the next two decades, each symposium on philology's present or future had to begin with the old topic of its unfear neglect, all the more painful as those who would discuss the matter knew that philology had once been in the van of the scientific inquiry and, like the natural sciences, had offered a valid paradigm of knowledge. But in 2009, in Future Philology? The Fate of a Soft Science in a Hard World, the Indologist Sheldon Pollock contributed a different note to the chorus of lamentations, suggesting a few measures towards the reconstruction

*Email address:chiriladina@yahoo.com. 
of philology, "at what seems like two minutes before our planet's midnight" (Pollock, 2009, p. 933), while pointing to the causes of its decline (among which the philologists' failure to make a strong case for their own discipline either explicitly or by practice; idem, p. 934; v. et seq.). In Pollock's opinion, philologylike other sciences-must meet certain minimal requirements, if it is to re-live, nowadays, a second zenith, as a reflexive philology capable to produce theoretically informed intellectual practices, as well as generalizations of a higher-order: 1) to gain awareness of its own historicity; 2) to embrace universality; 3 ) to reach a methodological-conceptual pluralism ${ }^{1}$. Thus Pollock goes beyond the first pertinent question - concerning the very possibility of constructing these three key factors, while all the other questions remain open: how is this supposed to be done ? $^{2}$, do the small vernacular philologies play any role in the construction of "universality"?, what does the "history" of philology mean: the history of restorative techniques in respect of the form originally intended by a text's primary author?, or is it a history of the expression of the human spirit through language, which pays little attention to the "artificial" lines that separate the new disciplines of the language and literature departments, and affirms, instead, that everything is philology?, what should we begin with? etc.

Although irrespective of Sheldon Pollock's ${ }^{3}$ program-the book's first draft was prepared in 2007-2008-, James Turner's ${ }^{4}$ Philology. 1. The Forgotten Origins of the Modern Humanities represents a possible solution to the first request of the American Indologist.

The book is a history of philology, conspicuous by two facts: first, being so rich in data, names and ideas, it meets the evident ambition of writing a comprehensive $^{5}$ (if not exhaustive ${ }^{6}$ ) history of the Western humanities; second, and most important, it is grounded on a view that enables it to extend over disciplines of a centrifugal modernism, which usually accept the patronage of a philology that is "love of words/knowledge" only: linguistics, literary critic, literary theory, anthropology, etc.

These two aspects-which, in fact, have forced the author towards a change of the narrative strategy, after one third of the book-entitle the reader to divide the book in two major parts, although its Contents refer to three substantial parts: I. From the First Philologists to 1800, p. 1-121; II. On the Brink of the Modern Humanities, 1800 to the Mid-nineteenth Century, p. 123-229; III. The Modern Humanities in the Modern University, the Mid-Nineteenth to the Twentieth Century, p. 231-379. First, predictably, Turner follows the beginnings of philological practice in Antiquity (as linguistic speculation, rhetoric, textual philology and grammar; p. 3-25) and its developments, through the Middle Ages (which, while struggling to understand the content and message of the sacred texts, preferred the abstract logic, philosophy and theology of the scholastics over philology, and granted the latter merely means for a precarious survival; p. 25-32) and the Renaissance (animated by humanists who would restore vigour, prestige and authority to philology, including in matters concern-

1 "First, twenty-first-century disciplines cannot remain arrogantly indifferent to their own historicity, constructedness, and changeability - this is an epistemological necessity, not a moral preference - and accordingly, the humbling force of genealogy must be part and parcel of every disciplinary practice. Second, disciplines can no longer be merely particular forms of knowledge that pass as general under the mask of science; instead, they must emerge from a new global, and preferably globally comparative, episteme and seek global, and preferably globally comparative, knowledge. Last, coming to understand by what means and according to what criteria scholars in past eras have grounded their truth-claims must be part of — not the whole of, but part of-our own understanding of what truth is and key dimension of what we might call our epistemic politics." (Pollock, 2009, p. 948).

${ }^{2}$ Since during the twentieth century many a book have been written on various problems concerning the modern philology, this particular question is accompanied by another: why does the result of these discussions continue to be insufficient and unsatisfactory? (cf. Pollock, 2009, p. 934-935.

${ }^{3}$ Turner cites Pollock only once, about their common consternation given the increasing ignorance of the public concerning the meaning of the word philology (p. IX; $c f$. Pollock, 2009, p. 933. $V$. Turner \& Harrington, 2016).

${ }^{4} J a m e s$ Turner is an intellectual historian, Cavanaugh Professor of Humanities, Emeritus, at the University of Notre Dame, Indiana.

${ }_{5}^{5}$ Eloquent in this respect are the dimensions of the critical apparatus at the end of the book: Notes, p. 387-452; Works Cited, p. 453-507; Index, p. 509-550.

${ }^{6}$ The book has been well received, with general appreciations like this one: “...this book is the most comprehensive history of the humanities we have in English today" (Hui, 2017, p. 145); v. also, from the forth cover of the book: "James Turner's book on 'philology' must be the most wide-ranging work of intellectual history for many years." (Colin Burrow, London Review of Books). 
ing the Bible: Lovato dei Lovati, Petrarca, Lorenzo Valla, Poliziano, Erasmus din Rotterdam, Joseph Scalinger, Beatus Rhenanus, Hugo Grotius, Thomas Hobbs, Baruch Spinoza, etc.; p. 33-64), until the end of the eighteenth century (when scholars like Richard Bentley, John Mill, John Locke-within the methodological frames previously established for the study of the cultural products of Antiquity, now enriched by a more profound understanding of the phenomenon of continuous social and linguistic evolution-would illuminate new facts from and about the core of the antique literature, and would extend the philological inquiry to cultures other than the classical, thus exemplary, ones; p. 65-90; $v$. also p. 91-120).

The author thoroughly records all these contributions, highlighting the specificities that made the philology (and the connected disciplines: historiography, antiquarianism, etc.) of the mideighteenth century look different from that of the mid-seventeenth century, and, likewise, the 1800 philology, from the 1750 philology. And then, he makes a crucial statement: "[b]ut these novelties grew organically from old ways, not from inventing radically new ones" (p. 90, emphasis added). The actual existence of a system of philological principles that multiply in order to become the vital force in new research directions is the central idea of Turner's masterly Philology..., the conception upon which the book stands ${ }^{7}$ and the view in favour of which it pleads.

To facilitate the demonstration, Turner structures the rest of the book in chapters that follow the growth of the new humanistic disciples stemming from philology and their development into the twentieth century. Thus, the chronological narration of the gains of the human spirit and understanding towards myriads of textual enigmas - from Antimachus of Colophon, who "studied Homer's language and prepared the first known 'edition' of Homer", from Aristotle's now lost work Homeric Problems, from Zenodotus of Ephesus and Eratosthenes of Cyrene, etc. (p. 5-14), to the novelties brought by the German philology, through J.D. Michaelis, J.J. Griesbach, J.G. Eichhorn, J.J. Winckelmann, etc., in biblical and classical studies, during the last decades of the eighteenth century (p. 112-119) - is replaced by a structure composed of several diachronic parallels, corresponding to linguistics, literature, classical studies, history, art history, anthropology, for 1800-1850/1860, and to all of these plus religious studies, for 1850/1860-1910/1920. Turner aims at demonstrating the fact that each of these approaches (aspiring at the title of independent sciences) hides in fact a threefold reinforcing of philological nature and tradition: i.e., 1. Comparison - 2. Verifiable interpretation of data - 3. Contextualization. And he does it by analysing the method that certain authors have used in the process of elaborating some of the most spectacular scientific works in their respective field.

Following this line of argumentation, the book does not have a conclusion. Instead, the reader finds at the end of the book (v. Epilogue, p. 381-386) a strong reiteration of the statements that open or close some of its chapters ${ }^{8}$ : “...what do archæology, art history, classics, social and cultural anthropology, history, literature, linguistics, and religious studies have in common? All descended from early modern philology and its companions antiquarianism and rhetoric - just as these early modern studies had derived from their ancient equivalents. As in other families, children do not each get an identical mix of genes. Archæology inherits more from antiquarianism than from philology. Literary criticism owes much to rhetoric, little to philology; in literary history the pattern reverses. By now, none of this should surprise. What needs emphasis is that common methods, a common mode of knowledge, survive in all disciplines within the philological family. All are interpretative in method; all deploy comparison in making their interpretations; all are sensitive to context, cultural or textual or visual; all believe historical lineages of some sort essential to understanding; all think that ideas, texts, paintings, institutions, artefacts, languages are products of history, shaped by

\footnotetext{
${ }^{7}$ In a recent interview, Turner explains once again: "My interest in philology began with a puzzle. [...] beginning about the middle of the nineteenth century, our present-day humanities disciplines rapidly developed in British, Irish, and North American universities. Where did they came from? In investigating early teachers of the modern humanities, I noticed that these men and (a few) women typically approached their subjects with methods borrowed from a very old source: philology and related studies. That observation was the «aha» moment that led me deep into the history of philology and its role as the seedbed of the modern humanities." (Turner \& Harrington, 2016).

${ }^{8}$ Sometimes, this might give the impression of repetitiveness.
} 
their historical context." (p. 382-383).

In James Turner's opinion, the measure of humanities' value and, as a consequence, the measure of philology's chance to last are given by the authors' power and knowledge to build upon this old and common vein. A practice as such would bring important benefits: first, awareness about the natural relations among disciplines (the sole legitimate synchrony! $)^{9}$; second, stimulation of an encyclopxdic instruction, a return to the golden age of knowledge, unfractured by the rigid principle of disciplinarity (p. 383). Is this a utopian goal (cf. Hui, 2017, p. 146)? Facing the huge volume of information ${ }^{10}$ that, in this case, should be comprehended, Turner reminds the reader of several moments in human history when humanity had to deal with similar difficulties and managed to conquer them: the development of filters for the selection of essential data for surviving and breeding, in Homo sapiens; the refinement of techniques and technologies applied in organizing data and information, like Ciceronian "memory palaces", and note-taking methods, in Renaissance (p. 383); and the model provided by the natural science, which accepted to be reorganised into flexible units: biochemistry, biophysics, biomedical informatics, astrophysics, biogeochemistry, etc. (p. 385). Meanwhile-bitterly observes the historian- "English and history departments soldier stolidly on, muskets on their shoulders. But ultimately stasis will not serve." (p. 386).
Philology. 1. The Forgotten Origins of the Modern Humanities may be seen as a first step towards the renewal of the contemporary philology. It is not a history of the universal philology, though (as envisioned by Sheldon Pollock), since it does not follow the tradition of textual and linguistic inquiry in different geo-cultural spaces, Oriental and Occidental $(v$. in fact Turner's whimsical confession about neglecting - and, thus, delivering it from erroneous interpretations - the issue of Chinese philology, p. 381). It seems that the author did not intend to write anything but a history of philological practices, exemplified by English scholarly literature. The fact that two chapters from the second part of the book (7, "An Epoch in Historical Science". The Civilized Past, 1800-1850, p. 167-209; and 8, "Grammatical and Exegetical Tact". Biblical Philology and its Others, 1800-1860, p. 210-229) report amply on the work of German philologists is justified through the essential role that the Germans have played in establishing a rigorous science of the Antiquity [Germ. Altertumswissenschaft], through B.G. Niebuhr's Römische Geschichte, in 1812, as a model of inquiry for fellow researchers throughout the Continent. Grasping the reason of this special attitude towards the German contribution, one cannot upbraids the American historian with paying so little attention to the development of the modern French or Italian philology (cf. Hui, 2017, p. 148).

\section{References}

Bloch, H.R. (1990). New Philology and Old French, in "Speculum", vol. 65, issue 1, p. 38-58, CrossRef.

Hui, A. (2017). The Many Returns of Philology: A State of the Field Report, in "Journal of the History of Ideas", vol. 78, issue 1, p. 137156, CrossRef.

Nichols, S.G. (1990). Philology in a Manuscript Culture (Introduction), in "Speculum”, vol. 65, issue 1, p. 1-10, CrossRef.

Pollock, S. (2009). Future Philology? The Fate of a Soft Science in a Hard World, in "Critical Inquiry", vol. 35, issue 4, p. 931-961, CrossRef.

Turner, J. \& Harrington, A. (2016). Voices and Ideas. On Philology: Interview with James Turner, in 'The Key Reporter”. Phi Beta Kappa's Publication for News and Alumni Relations, [online].

Wenzel, S. (1990). Reflections on (New) Philology, in "Speculum”, vol. 65, issue 1, p. 11-18, CrossRef.

\footnotetext{
${ }^{9}$ And the only one which, not being synonymous with the isolationism, saves the contemporary humanities from a quasiundignified state: "[present-day humanities are] artificial creations - where made-up lines pretend to divide the single sandbox in which we all play into each boy's or girl's own inviolable kingdom. It is a sham.” (p. 385).

${ }^{10} \mathrm{~A}$ fact used as an excuse for increasingly narrow specializations.
} 